\title{
Coronary Embolism and Myocardial Infarction: A Scoping Study
}

\author{
Pramod Theetha Kariyanna, ${ }^{1,2}$, Benjamin Ramalanjaona ${ }^{1,2}$, Mohammed Al-Sadawi ${ }^{1,2}$, \\ Apoorva Jayarangaiah ${ }^{3}$, Sudhanva Hegde ${ }^{1,2}$, Isabel M. McFarlane ${ }^{1,2, *}$ \\ ${ }^{1}$ Department of Internal Medicine, Division of Cardiology, SUNY, \\ Downstate Health Sciences University, Brooklyn, N.Y., U.S.A-11203 \\ ${ }^{2}$ Division of Cardiovascular Disease, Department of Internal Medicine, State University of New York, \\ Downstate Health Sciences University, NYC Health + Hospitals/Kings County, Brooklyn, N.Y., U.S. \\ ${ }^{3}$ Department of Internal Medicine, NYC Health + Hospitals/Jacobi Medical Center, Bronx, N.Y., U.S.A-10461 \\ *Corresponding author: isabel.mcfarlane@downstate.edu
}

Received November 01, 2019; Revised December 05, 2019; Accepted December 17, 2019

\begin{abstract}
Coronary embolism is a cause of acute myocardial infarction (AMI)in which obstructive foci enter the coronary circulation, block normal blood flow and precipitate ischemia. Precise studies focusing on patient population affected, pathophysiological mechanisms, and treatment strategies are scanty, in spite of a reported prevalence estimated at $2.9 \%$. As the understanding of myocardial infarction without evidence of coronary artery disease continues to grow, an in-depth review of this previously seldomly reported subtype of coronary ischemia was in order. Patients suffering coronary embolism are 15 to 20 years younger than traditional AMI patients with a slight predominance towards male sex, which resembles the gender data of the populations affected by nontraditional myocardial infarction in published reports. While the expected prevalence rate of cardiovascular disease risk factors such as hypertension and hyperlipidemia are present, this population also has a relatively high prevalence of atrial fibrillation and valve pathology, especially endocarditis. Initial presentation is indistinguishable from other causes of myocardial infarction however fever is commonly present, when endocarditis with valvular involvement is the primary cause of the coronary embolism. Mechanical thrombectomy is the mainstay of treatment, followed by percutaneous coronary intervention. Mortality is the highest in patients who do not receive targeted treatment for the coronary embolism, particularly if only antimicrobial agents or anticoagulation without thrombolytic agents are employed. The unique features of coronary embolism highlighted in this historical study justify further examination in contemporary patient populations.
\end{abstract}

Keywords: coronary embolism, acute myocardial infarction, non-traditional myocardial infarction, paradoxical coronary embolism, infectious endocarditis, valvular vegetations, atrial fibrillation, cardiovascular risk factors, prosthetic heart valve, thrombolytic therapy, management of coronary embolism

Cite This Article: Pramod Theetha Kariyanna, Benjamin Ramalanjaona, Mohammed Al-Sadawi, Apoorva Jayarangaiah, Sudhanva Hegde, and Isabel M. McFarlane, "Coronary Embolism and Myocardial Infarction: A Scoping Study.” American Journal of Medical Case Reports, vol. 8, no. 2 (2020): 31-43. doi: 10.12691/ajmcr-8-2-1.

\section{Introduction}

Heart disease is the leading cause of morbidity and mortality worldwide [1]. In the United States, heart attack or acute myocardial infarction (AMI) has an annual incidence of about 805,000 cases with a death rate of 96.8 per 100,000 [2]. Though coronary artery disease (CAD) is the most common cause of AMI [3], infarction can happen without significant coronary artery stenosis. Myocardial infarction with nonobstructive coronary arteries (MINOCA) includes syndromes of the epicardium, microvasculature, and emerging concepts like myocardial necrosis due to oxygen supply-demand mismatch [4]. A systematic review of
27 clinical trials/AMI registries reports MINOCA prevalence of $6 \%$ of AMI cases [5].

Coronary embolism (CE) is a heterogenous cause of MINOCA that can be divided into direct, paradoxical, and iatrogenic [6]. Direct CE is when an embolism enters the coronary circulation, originating from systemic circulation or an intracardiac focus on the left side of the heart. Paradoxical CE enters coronary circulation after passing from venous circulation via a septal defect or patent foramen oval. Iatrogenic encompasses any emboli associated with a procedure, usually cardiothoracic surgery or percutaneous coronary intervention (PCI). There is overlap between the different categories and other organization schema have also been proposed. 
In spite of early autopsy series identifying CE [7] and advancements in cardiovascular imaging, prevalence of $\mathrm{CE}$ has not yet been evaluated across multiple trials/registries. A single center, retrospective study of 1776 de novo AMI patients reports CE prevalence of $2.9 \%$ of AMI cases [8]. As it could represent almost half of MINOCA cases, CE should not be considered a rare entity. We here undertake the first scoping study of CE to understand risk factors, diagnosis, sources of emboli, management, and mortality.

\section{Methods}

On July 23rd, 2019, a systematic search was conducted using Pubmed, Google Scholar, CINAHL, Cochrane CENTRAL and Web of Science databases. Studies listing the keywords "embolism, myocardial infarction" were used to identify cases of myocardial arrhythmias associated with marijuana use. The reference list of each report was reviewed for potential additional cases. All cases were reviewed in detail. Data reviewed included demographic data, cardiovascular (CV) risk factors, electrocardiography (EKG) findings, troponin levels, transthoracic echocardiography, electrophysiology study, urine drug screen findings, coronary angiogram and management when available.

\section{Results}

\subsection{Demographics}

A total of 232 unique cases were identified in 190 publications (Table 1). Males comprised $55.2 \%$ of the cases reported and females comprised $44.8 \%$. Overall age range was 4 months to 87 years with mean $50.2 \pm 17.9$ years and median 51 years; $57.3 \%$ of cases were younger than 55 years and $42.7 \%$ of cases were 55 years or older. Male age range was 4 months to 87 years with mean 49.6 \pm 18.1 years and median 51 years. Female age was 12 to 87 years with mean $51.0 \pm 17.9$ years and median 51 years (Table 2).

Table 1. Cases of CE included in the study

\begin{tabular}{|c|c|c|c|}
\hline Serial Number & Year & Author & Reference \\
\hline 1 & 1950 & Moragues et al. & {$[39]$} \\
\hline 2 & 1952 & Walker et al. & {$[40]$} \\
\hline 3 & 1952 & Glushien et al. & {$[41]$} \\
\hline 4 & 1954 & Segall et al. & {$[42]$} \\
\hline 5 & 1958 & Gill et al. & {$[43]$} \\
\hline 6 & 1958 & Hoffman et al. & {$[44]$} \\
\hline 7 & 1958 & Lillington et al. & {$[45]$} \\
\hline 8 & 1958 & Kavanaugh et al. & {$[46]$} \\
\hline 9 & 1959 & Boas et al. & {$[47]$} \\
\hline 10 & 1959 & Gelpi et al. & {$[48]$} \\
\hline 11 & 1958 & Wegner et al. & {$[49]$} \\
\hline 12 & 1960 & Marietta et al. & {$[50]$} \\
\hline 13 & 1960 & Winters et al. & {$[51]$} \\
\hline 14 & 1961 & Menzies et al. & {$[52]$} \\
\hline 15 & 1961 & Oakley et al. & {$[53]$} \\
\hline 16 & 1961 & Miyahara et al. & {$[54]$} \\
\hline
\end{tabular}

\begin{tabular}{|c|c|c|c|}
\hline Serial Number & Year & Author & Reference \\
\hline 17 & 1962 & Jerie et al. & [55] \\
\hline 18 & 1962 & Shanoff et al. & [56] \\
\hline 19 & 1964 & Rivera et al. & [57] \\
\hline 20 & 1965 & Liban et al. & [58] \\
\hline 21 & 1965 & Harris et al. & [59] \\
\hline 22 & 1966 & Watt et al. & {$[60]$} \\
\hline 23 & 1967 & Ritch et al. & [61] \\
\hline 24 & 1968 & Woo-Ming et al. & [62] \\
\hline 25 & 1969 & Tsuchiya et al. & [63] \\
\hline 26 & 1969 & Parameswaran et al. & [64] \\
\hline 27 & 1969 & Reddy et al. & [65] \\
\hline 28 & 1969 & Hall et al. & {$[66]$} \\
\hline 29 & 1971 & Benchimol et al. & [67] \\
\hline 30 & 1971 & Richardson et al. & [68] \\
\hline 31 & 1974 & Hartveit et al. & [69] \\
\hline 32 & 1974 & Schatz et al. & [70] \\
\hline 33 & 1974 & Attai et al. & [71] \\
\hline 34 & 1976 & Pfeifer et al. & [72] \\
\hline 35 & 1977 & Fayemi et al. & [73] \\
\hline 36 & 1978 & Bedetti et al. & [74] \\
\hline 37 & 1978 & Saenz et al. & [75] \\
\hline 38 & 1979 & Sridhar et al. & [76] \\
\hline 39 & 1979 & McHenry et al. & [77] \\
\hline 40 & 1982 & Lin et al. & [78] \\
\hline 41 & 1984 & Przybojewski et al. & [79] \\
\hline 42 & 1984 & Przybojewski et al. & {$[80]$} \\
\hline 43 & 1985 & Marx et al. & {$[81]$} \\
\hline 44 & 1986 & Ueda et al. & {$[82]$} \\
\hline 45 & 1986 & Presant et al. & [83] \\
\hline 46 & 1987 & Culver et al. & {$[84]$} \\
\hline 47 & 1987 & Maddoux et al. & [85] \\
\hline 48 & 1987 & Ackermann et al. & [86] \\
\hline 49 & 1988 & Mercereau et al. & {$[87]$} \\
\hline 50 & 1988 & Backer et al. & [88] \\
\hline 51 & 1988 & Jungbluth et al. & [89] \\
\hline 52 & 1990 & Vasiljevic et al. & [90] \\
\hline 53 & 1991 & Herzog et al. & [91] \\
\hline 54 & 1992 & Valente et al. & [92] \\
\hline 55 & 1993 & Bell et al. & [93] \\
\hline 56 & 1995 & Eckstein et al. & [94] \\
\hline 57 & 1996 & Haynes et al. & [95] \\
\hline 58 & 1996 & Abascal et al. & [96] \\
\hline 59 & 1997 & Iwama et al. & {$[97]$} \\
\hline 60 & 1998 & Quinn et al. & [98] \\
\hline 61 & 1998 & Matsumoto et al. & [99] \\
\hline 62 & 1999 & Lanza et al. & {$[100]$} \\
\hline 63 & 2000 & Perera et al. & {$[101]$} \\
\hline 64 & 2000 & Takada et al. & {$[102]$} \\
\hline 65 & 2000 & Tun et al. & [103] \\
\hline 66 & 2000 & Chan et al. & [104] \\
\hline 67 & 2001 & Mentzelopoulos et al. & [105] \\
\hline 68 & 2002 & Aslam et al. & {$[106]$} \\
\hline 69 & 2002 & Beldner et al. & {$[107]$} \\
\hline 70 & 2002 & Hernández et al. & {$[108]$} \\
\hline 71 & 2002 & Tobar et al. & [109] \\
\hline 72 & 2003 & Hung et al. & {$[110]$} \\
\hline 73 & 2003 & Ramos et al. & {$[111]$} \\
\hline 74 & 2003 & Meier-Ewert et al. & {$[112]$} \\
\hline 75 & 2004 & Kotooka et al. & [113] \\
\hline 76 & 2004 & Mahmood et al. & [114] \\
\hline 77 & 2004 & Haghi et al. & {$[115]$} \\
\hline 78 & 2004 & Eguchi et al. & {$[116]$} \\
\hline 79 & 2004 & Orban et al. & [117] \\
\hline
\end{tabular}




\begin{tabular}{|c|c|c|c|}
\hline Serial Number & Year & Author & Reference \\
\hline 80 & 2004 & Petinaux et al. & [118] \\
\hline 81 & 2005 & Ozaydin et al. & [119] \\
\hline 82 & 2005 & Adachi et al. & [120] \\
\hline 83 & 2014 & Deepali et al. & [121] \\
\hline 84 & 2005 & Braun et al. & [122] \\
\hline 85 & 2005 & Taniike et al. & [123] \\
\hline 86 & 2005 & Pindado et al. & [124] \\
\hline 87 & 2005 & Kirkpatrick et al. & [125] \\
\hline 88 & 2006 & Vanoverbeke et al. & [126] \\
\hline 89 & 2006 & Kiernan et al. & [127] \\
\hline 90 & 2006 & Mejia et al. & [128] \\
\hline 91 & 2006 & Cay et al. & [129] \\
\hline 92 & 2006 & Bodor et al. & [130] \\
\hline 93 & 2006 & Bracco et al. & [131] \\
\hline 94 & 2006 & Breithardt et al. & [132] \\
\hline 95 & 2006 & Wilson et al. & [133] \\
\hline 96 & 2007 & Yazici et al. & [134] \\
\hline 97 & 2007 & Sakai et al. & [135] \\
\hline 98 & 2007 & Van de Walle et al. & [136] \\
\hline 99 & 2007 & Ural et al. & [137] \\
\hline 100 & 2007 & Greig et al. & [138] \\
\hline 101 & 2008 & Yavari et al. & [139] \\
\hline 102 & 2008 & Caciolli et al. & {$[140]$} \\
\hline 103 & 2008 & Baek et al. & [141] \\
\hline 104 & 2009 & Kessavane et al. & [142] \\
\hline 105 & 2009 & Nanjappa et al. & [143] \\
\hline 106 & 2009 & Murthy et al. & [144] \\
\hline 107 & 2009 & Martín et al. & [145] \\
\hline 108 & 2009 & Camaro et al. & [146] \\
\hline 109 & 2009 & Lacunza-Ruiz et al. & [147] \\
\hline 110 & 2009 & Sial et al. & [148] \\
\hline 111 & 2009 & Budavari et al. & [149] \\
\hline 112 & 2009 & Teixera et al. & [150] \\
\hline 113 & 2009 & Lin et al. & [151] \\
\hline 114 & 2009 & Dogan et al. & [152] \\
\hline 115 & 2009 & Steinwender et al. & [153] \\
\hline 116 & 2009 & Shim et al. & [154] \\
\hline 117 & 2010 & Ferlan et al. & [155] \\
\hline 118 & 2010 & Nakazone et al. & [156] \\
\hline 119 & 2010 & Pawlaczyk et al. & [157] \\
\hline 120 & 2010 & Motreff et al. & [158] \\
\hline 121 & 2010 & Bae et al. & [159] \\
\hline 122 & 2011 & Yuce et al. & {$[160]$} \\
\hline 123 & 2011 & Levis et al. & [161] \\
\hline 124 & 2011 & Saraiva et al. & [162] \\
\hline 125 & 2011 & Gavrielatos et al. & [163] \\
\hline 126 & 2011 & George et al. & [164] \\
\hline 127 & 2011 & Najib et al. & [165] \\
\hline 128 & 2011 & Acikel et al. & [166] \\
\hline 129 & 2011 & Roxas et al. & [167] \\
\hline 130 & 2011 & Rifai et al. & [168] \\
\hline 131 & 2011 & Vasconcellos et al. & [169] \\
\hline 132 & 2012 & Aykan et al. & {$[170]$} \\
\hline 133 & 2012 & Martin et al. & {$[171]$} \\
\hline 134 & 2012 & Marella et al. & [172] \\
\hline 135 & 2012 & Bennett et al. & [173] \\
\hline 136 & 2012 & Staico et al. & [174] \\
\hline 137 & 2012 & Brito et al. & {$[175]$} \\
\hline 138 & 2012 & Kaya et al. & [176] \\
\hline 139 & 2013 & Kim et al. & [177] \\
\hline
\end{tabular}

\begin{tabular}{|c|c|c|c|}
\hline Serial Number & Year & Author & Reference \\
\hline 140 & 2013 & Karavelioğlu et al. & [178] \\
\hline 141 & 2013 & Smith et al. & [179] \\
\hline 142 & 2013 & Angulo-Llanos et al. & [180] \\
\hline 143 & 2013 & Zasada et al. & [181] \\
\hline 144 & 2013 & Kirubakaran et al. & [182] \\
\hline 145 & 2013 & Tiong et al. & [183] \\
\hline 146 & 2014 & Lacunza-Ruiz et al. & [184] \\
\hline 147 & 2014 & Tsang et al. & [185] \\
\hline 148 & 2014 & Karaoyun et al. & [186] \\
\hline 149 & 2014 & Abecasis et al. & [187] \\
\hline 150 & 2014 & Giri et al. & [188] \\
\hline 151 & 2014 & Gagliardi et al. & [189] \\
\hline 152 & 2014 & Seo et al. & [190] \\
\hline 153 & 2014 & Kitkungvan et al. & [191] \\
\hline 154 & 2014 & Dauvergne et al. & [192] \\
\hline 155 & 2014 & Steiner et al. & [193] \\
\hline 156 & 2014 & Heseltine et al. & [194] \\
\hline 157 & 2015 & Wee et al. & [195] \\
\hline 158 & 2015 & Senguttuvan et al. & [196] \\
\hline 159 & 2015 & Plymen et al. & [197] \\
\hline 160 & 2015 & Iannaccone et al. & [198] \\
\hline 161 & 2015 & Medda et al. & [199] \\
\hline 162 & 2015 & Wongrakpanich et al. & [200] \\
\hline 163 & 2015 & Mallouppas et al. & [201] \\
\hline 164 & 2015 & Nakamura et al. & [202] \\
\hline 165 & 2015 & Mallouppas et al. & [203] \\
\hline 166 & 2015 & Hartung et al. & [204] \\
\hline 167 & 2015 & Sultan et al. & [205] \\
\hline 168 & 2016 & Koutsampasopoulos et al. & [206] \\
\hline 169 & 2016 & Castelli et al. & [207] \\
\hline 170 & 2016 & Winkler et al. & [208] \\
\hline 171 & 2016 & Zachura et al. & [209] \\
\hline 172 & 2016 & Ito et al. & [210] \\
\hline 173 & 2014 & Sousa et al. & [211] \\
\hline 174 & 2016 & Nogales-Romo et al. & [212] \\
\hline 175 & 2016 & Chikkabasavaiah et al. & [213] \\
\hline 176 & 2016 & Rozado et al. & [214] \\
\hline 177 & 2017 & Rotta Detto Loria et al. & [215] \\
\hline 178 & 2017 & Liu et al. & [216] \\
\hline 179 & 2017 & Rivera-Juárez et al. & [217] \\
\hline 180 & 2017 & Sinha et al. & [218] \\
\hline 181 & 2017 & Manchurov et al. & [219] \\
\hline 182 & 2017 & Pavani et al. & [220] \\
\hline 183 & 2017 & Dallaglio et al. & [221] \\
\hline 184 & 2017 & Martinez et al. & [222] \\
\hline 185 & 2018 & Cvetković et al. & [223] \\
\hline 186 & 2018 & Sakagami et al. & [224] \\
\hline 187 & 2017 & Jiao et al. & [225] \\
\hline 188 & 2016 & Ahmad et al. & [226] \\
\hline 189 & 2017 & Cay et al. & [227] \\
\hline 190 & 2016 & Virk et al. & [228] \\
\hline
\end{tabular}

Table 2. Study population demographics $(n=232)$

\begin{tabular}{|l|c|c|c|}
\hline & Total & Males & Females \\
\hline Age (years) & & & \\
Mean (SD) & $50.2(17.9)$ & $49.6(18.1)$ & $51(17.7)$ \\
Range & 0.3 to 87 & 0.3 to 87 & 12 to 87 \\
\hline Gender & & & \\
Male n (\%) & $128(55.2)$ & & \\
Female n (\%) & $104(44.8)$ & & \\
\hline
\end{tabular}




\subsection{Cardiovascular Risk Factors}

The most prevalent cardiovascular risk factors and comorbidities in the population were as follows: atrial fibrillation $17.2 \%$, hypertension $16.8 \%$, hyperlipidemia $15.9 \%$, prosthetic heart valves $15.9 \%$, chronic valvular disease not treated with valve replacement $15.9 \%$, rheumatic heart disease $12.5 \%$, diabetes $9.91 \%$, obesity $9.05 \%$, history of CAD $9.05 \%$, cerebrovascular disease $9.05 \%$, and smoking $8.62 \%$. Comprehensive risk factors and comorbidities are listed in Table 3.

Table 3. Historical cardiovascular risk factors $(n=232)$

\begin{tabular}{|c|c|}
\hline & N (\%) \\
\hline Atrial fibrillation & $40(17.2)$ \\
\hline Hypertension & 39 (16.8) \\
\hline Hyperlipidemia & 37 (15.9) \\
\hline Chronic Valvular Disease & 37 (15.9) \\
\hline Mitral valve & $21(9.05)$ \\
\hline Aortic valve & $16(6.90)$ \\
\hline Prosthetic heart valve & 37 (15.9) \\
\hline Mitral valve & $20(8.62)$ \\
\hline Aortic valve & $11(4.74)$ \\
\hline Aortic and mitral valves & $6(2.59)$ \\
\hline Rheumatic heart disease & $29(12.5)$ \\
\hline Valve unspecified & $18(7.76)$ \\
\hline Mitral & $9(3.88)$ \\
\hline Aortic & $2(0.862)$ \\
\hline Diabetes & $23(9.91)$ \\
\hline Coronary artery disease & $21(9.05)$ \\
\hline Cerebrovascular disease & $21(9.05)$ \\
\hline Obesity & $21(9.05)$ \\
\hline Smoking & $20(8.62)$ \\
\hline End stage renal disease & $9(3.88)$ \\
\hline Congestive heart failure & $7(3.02)$ \\
\hline Deep vein thrombosis/pulmonary embolism & $7(3.02)$ \\
\hline Valve vegetations & $7(3.02)$ \\
\hline Cardiomyopathy & $5(2.16)$ \\
\hline Atrial septal defect & $3(1.29)$ \\
\hline Alcohol abuse & $2(0.862)$ \\
\hline Drug abuse & $2(0.862)$ \\
\hline Other arrhythmia & $2(0.862)$ \\
\hline Aortic dissection & $2(0.862)$ \\
\hline Obstructive sleep apnea & $2(0.862)$ \\
\hline Anemia & $2(0.862)$ \\
\hline Patent foramen ovale & $2(0.862)$ \\
\hline Pregnancy & $2(0.862)$ \\
\hline Systemic lupus erythematosus & $2(0.862)$ \\
\hline Intracardiac thrombus & $2(0.862)$ \\
\hline Arteritis & $1(0.431)$ \\
\hline Aortic coarctation & $1(0.431)$ \\
\hline Hypertrophic obstructive cardiomyopathy & $1(0.431)$ \\
\hline Hyperthyroidism & $1(0.431)$ \\
\hline Liver disease & $1(0.431)$ \\
\hline Ventricular septal defect & $1(0.431)$ \\
\hline Endocarditis & $1(0.431)$ \\
\hline Heart transplant & $1(0.431)$ \\
\hline Tuberculosis & $1(0.431)$ \\
\hline
\end{tabular}

\subsection{Presentation}

Patients presented with chest pain $66.8 \%$, fever $19.0 \%$, sudden death $6.03 \%$, hypotension $3.35 \%$, shortness of breath $3.35 \%$, stroke $0.862 \%$, and without symptoms $0.431 \%$ (Table 4 ).
Table 4. Presenting complaints $(n=232)$

\begin{tabular}{|l|c|}
\hline & $\mathrm{n}(\%)$ \\
\hline Chest pain & $157(66.8)$ \\
Fever & $44(19.0)$ \\
Sudden death & $14(6.03)$ \\
Hypotension & $8(3.35)$ \\
Shortness of breath & $8(3.35)$ \\
Stroke & $2(0.862)$ \\
Asymptomatic & $1(0.431)$ \\
\hline
\end{tabular}

\subsection{ECG Findings}

In the 219 cases reporting ECG findings (Table 5), ST elevation was found in $43.8 \%$, ST depression in $11.4 \%$, unspecified "infarct changes" in $26.5 \%$, atrial fibrillation in $14.2 \%$, $\mathrm{T}$ wave changes in $10.5 \%$, and Q waves $3.65 \%$.

Table 5. Infarct ECG findings $(n=219)$

\begin{tabular}{|l|c|}
\hline & $\mathrm{n}(\%)$ \\
\hline ST changes & $114(52.1)$ \\
ST elevation & $96(43.8)$ \\
ST depression & $25(11.4)$ \\
ST change, unspecified & $3(1.37)$ \\
Infarct changes, unspecified & $58(26.5)$ \\
Atrial fibrillation & $31(14.2)$ \\
T wave changes & $23(10.5)$ \\
T wave inversion & $18(8.22)$ \\
T wave depression & $2(0.913)$ \\
T wave change, unspecified & $2(0.913)$ \\
Peaked T wave & $1(0.457)$ \\
Q waves & $8(3.65)$ \\
\hline
\end{tabular}

\subsection{Angiographic Findings}

A total of 173 cases included angiographic findings (Table 6). Occluded arteries were found in $95.4 \%$ of cases. Lesions were found in the left anterior descending artery $52.0 \%$, left circumflex artery $17.3 \%$, right main coronary artery $17.3 \%$, left main coronary artery $9.83 \%$, obtuse marginal artery $2.89 \%$, posterolateral artery $2.31 \%$, diagonal artery $1.73 \%$, and intermediate artery $0.578 \%$.

Table 6. Location of lesion on cardiac catheterization $(n=173)$

\begin{tabular}{|l|c|}
\hline & $\mathrm{n}(\%)$ \\
\hline Left anterior descending artery & $90(52.0)$ \\
Left circumflex artery & $30(17.3)$ \\
Right main coronary artery & $30(17.3)$ \\
Left main coronary artery & $17(9.83)$ \\
Posterior descending artery & $8(4.62)$ \\
No findings & $8(4.62)$ \\
Obtuse marginal artery & $5(2.89)$ \\
Posterolateral artery & $4(2.31)$ \\
Diagonal artery & $3(1.73)$ \\
Intermediate artery & $1(0.578)$ \\
\hline
\end{tabular}

\subsection{Trans-thoracic Echocardiography}

Of the 94 cases reporting TTE, the most common findings were wall motion abnormalities in $47.9 \%$ of cases, valvular dysfunction in $29.8 \%$, systolic dysfunction in $25.5 \%$, valve masses or vegetations in $22.3 \%$, intracardiac masses in $18.1 \%$, and chamber enlargement in $11.7 \%$. 
Normal studies were reported in $9.57 \%$ of cases; additional findings are listed in Table 7.

Table 7. Transthoracic echocardiography findings $(n=94)$

\begin{tabular}{|l|c|}
\hline & $\mathrm{N}(\%)$ \\
\hline Wall motion abnormalities & $45(47.9)$ \\
Valvular dysfunction & $28(29.8)$ \\
Mitral regurgitation & $13(13.8)$ \\
Aortic regurgitation & $9(9.57)$ \\
Tricuspid regurgitation & $3(3.19)$ \\
Prosthetic valve & $2(2.13)$ \\
Aortic stenosis & $1(1.06)$ \\
Mitral valve prolapse & $1(1.06)$ \\
Systolic dysfunction & $24(25.5)$ \\
Valve mass or vegetation & $21(22.3)$ \\
Intracardiac mass & $17(18.10$ \\
LV & $8(8.51)$ \\
LA & $7(7.45)$ \\
RA & $2(2.13)$ \\
Chamber enlargement & $11(11.7)$ \\
RV & $5(5.32)$ \\
LV & $3(3.19)$ \\
RA & $2(2.13)$ \\
LA & $1(1.06)$ \\
Normal & $9(9.57)$ \\
Pulmonary hypertension & $4(4.26)$ \\
PFO & $3(3.19)$ \\
Cardiomyopathy & $2(2.13)$ \\
Aortic dissection & $1(1.06)$ \\
\hline
\end{tabular}

\subsection{Trans-esophageal Echocardiography}

Transesophageal echocardiograms were reported in 63 cases. The most common findings were valves masses or vegetations in $39.7 \%$ of cases, intracardiac masses in $33.3 \%$, and valvular dysfunction in $25.4 \%$. Other findings are listed in Table 8.

Table 8. Transesophageal echocardiography findings $(n=63)$

\begin{tabular}{|l|c|}
\hline & $\mathrm{N}(\%)$ \\
\hline Valve mass or vegetation & $25(39.7)$ \\
LA & $21(33.3)$ \\
LV & $17(27.0)$ \\
RA & $2(3.17)$ \\
Valvular dysfunction & $2(3.17)$ \\
Mitral regurgitation & $16(25.4)$ \\
Prosthetic valve & $9(14.3)$ \\
Aortic regurgitation & $3(4.76)$ \\
Aortic stenosis & $2(3.17)$ \\
Mitral valve prolapse & $1(1.59)$ \\
Wall motion abnormalities & $1(1.59)$ \\
Normal & $8(12.7)$ \\
PFO & $8(12.7)$ \\
Systolic dysfunction & $6(9.52)$ \\
Aortic mass & $6(9.52)$ \\
Pulmonary embolism & $3(4.76)$ \\
Gas bubbles & $1(1.59)$ \\
\hline
\end{tabular}

\subsection{Causes of Coronary Embolism}

The reason for $\mathrm{CE}$, as per the case authors, were endocarditis $22.8 \%$, prosthetic heart valve complications
15.1\%, thromboembolism $13.4 \%$, atrial fibrillation $12.5 \%$, iatrogenic $12.5 \%$, non-thrombotic embolic sources (including solid tumors, bone marrow, and septic emboli) $9.91 \%$, chronic valvular disease $8.62 \%$, and rheumatic heart disease $6.47 \%$. A comprehensive list of CE causes is listed in Table 9.

Table 9. Reason for thromboembolism $(n=232)$

\begin{tabular}{|c|c|}
\hline & $\mathrm{n}(\%)$ \\
\hline Endocarditis & $53(22.8)$ \\
\hline Valve unspecified & $23(9.91)$ \\
\hline Aortic valve & $11(4.74)$ \\
\hline Mitral valve & $10(4.31)$ \\
\hline Aortic and mitral valves & $5(2.16)$ \\
\hline Mitral and tricuspid valves & $1(0.431)$ \\
\hline Prosthetic heart valves & $35(15.1)$ \\
\hline Mitral valve only & $19(8.20)$ \\
\hline Aortic valve only & $10(4.31)$ \\
\hline Aortic and mitral valve & $6(2.59)$ \\
\hline Thrombus & $31(13.4)$ \\
\hline Left ventricular thrombus & $9(3.88)$ \\
\hline DVT & $9(3.88)$ \\
\hline Arterial thrombus & $5(2.16)$ \\
\hline Left atrial thrombus & $3(1.29)$ \\
\hline Right atrial thrombus & $2(0.862)$ \\
\hline Pulmonary artery thrombus & $2(0.862)$ \\
\hline Aortic cusp thrombus & $1(0.431)$ \\
\hline Atrial fibrillation & $29(12.5)$ \\
\hline Procedure/Iatrogenic & 29 (12.5) \\
\hline Valve repair/replacement & $11(4.74)$ \\
\hline PCI & $6(2.59)$ \\
\hline Ablation & $3(1.29)$ \\
\hline Coronary angiography & $2(0.862)$ \\
\hline ASD/VSD repair & $2(0.862)$ \\
\hline Ascending aortic dissection repair & $1(0.431)$ \\
\hline AV cusp decalcification & $1(0.431)$ \\
\hline Hip replacement & $1(0.431)$ \\
\hline Central venous nutrition injection & $1(0.431)$ \\
\hline Radial endarterectomy & $1(0.431)$ \\
\hline Non-thrombotic embolic source & $23(9.91)$ \\
\hline Solid tumor & $20(8.62)$ \\
\hline Septic & $2(0.862)$ \\
\hline Bone marrow & $1(0.431)$ \\
\hline Chronic valvular disease & $20(8.62)$ \\
\hline Mitral valve & $14(6.03)$ \\
\hline Aortic valve & $6(2.59)$ \\
\hline Rheumatic heart disease & $15(6.47)$ \\
\hline Mitral valve & $10(4.31)$ \\
\hline Valve unspecified & $4(1.72)$ \\
\hline Aortic valve & $1(0.431)$ \\
\hline PFO & $11(4.74)$ \\
\hline Hypercoagulable state & $8(3.35)$ \\
\hline Cardiomyopathy & $8(3.35)$ \\
\hline ASD & $5(2.16)$ \\
\hline Unknown & $5(2.16)$ \\
\hline MVP & $2(0.862)$ \\
\hline Other arrhythmia & $1(0.431)$ \\
\hline VSD & $1(0.431)$ \\
\hline Double chamber LV & $1(0.431)$ \\
\hline
\end{tabular}

\subsection{Management}

The most common interventions performed were thrombectomy $31.0 \%$, PCI $22.0 \%$ (stent placed in $31.4 \%$ of these cases), anticoagulation $14.7 \%$, thrombolytic 
therapy $9.48 \%$, and antibiotics/antifungals $8.19 \%$. A comprehensive list of interventions is listed in Table 10.

Table 10. Interventions $(n=232)$

\begin{tabular}{|l|c|}
\hline & $\mathrm{n}(\%)$ \\
\hline Thrombectomy & $72(31.0)$ \\
Aspiration thrombectomy & $53(22.8)$ \\
Mechanical thrombectomy & $11(4.74)$ \\
Surgical thrombectomy & $8(3.45)$ \\
PCI & $51(22.0)$ \\
Without stent placement & $31(13.4)$ \\
With stent placement & $16(6.90)$ \\
Anticoagulation & $34(14.7)$ \\
Anticoagulation alone & $25(10.8)$ \\
No intervention & $31(13.4)$ \\
Thrombolytic therapy & $22(9.48)$ \\
Antibiotics/antifungal & $19(8.19)$ \\
Antibiotics/antifungal alone & $17(7.33)$ \\
Excision of embolic source & $18(7.76)$ \\
Valve surgery & $18(7.76)$ \\
Intervention not reported & $18(7.76)$ \\
CABG & $8(3.45)$ \\
Antiplatelet therapy alone & $6(2.58)$ \\
PFO closure & $2(0.862)$ \\
Unspecified surgical intervention & $2(0.862)$ \\
Heart transplant & $1(0.431)$ \\
RVAD & $1(0.431)$ \\
Femoral vein clamp & $1(0.431)$ \\
\hline
\end{tabular}

\subsection{Mortality}

Death was reported in $35.7 \%$ of cases (Table 11 ), of which 34.9\% occurred after no intervention was performed, $15.7 \%$ after anticoagulation, $12.0 \%$ after antibiotic/antifungal therapy alone were given, $6.02 \%$ after surgical intervention, $4.82 \%$ after aspiration thrombectomy, 3.61\% after valve repair/replacement, and 2.41\% after thrombolytic therapy. Recurrence of coronary embolism was reported in 7 cases, 3 of which resulted in death.

Table 11. Mortality and intervention attempted $(n=83)$

\begin{tabular}{|l|c|}
\hline & $\mathrm{n}(\%)$ \\
\hline No intervention & $29(34.9)$ \\
Anticoagulation & $13(15.7)$ \\
Anticoagulation alone & $12(14.5)$ \\
Antibiotics/antifungals alone & $10(12.0)$ \\
Surgical intervention & $5(6.02)$ \\
Aspiration thrombectomy & $4(4.82)$ \\
Valve surgery & $3(3.61)$ \\
Thrombolytic therapy & $2(2.41)$ \\
\hline
\end{tabular}

\section{Discussion}

The average age in the study population was approximately 15 years younger for males and 20 years younger for females than expected for all causes of MI, with females also representing a smaller percentage in all age groups relative to men than expected for all causes of MI [9]. While younger age and skew towards male sex may be due to small sample size and known underdiagnosis of MI in females [10], these demographic data correlate with findings in larger reviews of MINOCA [5]. Whether there is a unique patient population for $\mathrm{CE}$ should be confirmed in future studies.

Risk factors for CE overlapped with those for MI due to CAD (MI-CAD), specifically hypertension, hyperlipidemia, diabetes, CAD, CVD, and smoking. History of atrial fibrillation (AF), which is more commonly associated with cerebrovascular disease (CVD), was present in $17.2 \%$ of patients. Given the risk of thrombus formation in the left atrium in AF and its proximity to the coronary aortic cusps, thromboembolic events can occur in a similar fashion in the coronary circulation as they do in CVD. CE may occur less frequently than CVD in this setting due to the fast rate of flow of blood across the coronary ostia, high resistance to flow of the smaller caliber coronary vessels as dictated by Poiseuille's Law, and the acute angle of the origin of the coronary arteries [11]. Interestingly, demand ischemia from AF with rapid ventricular response has also been proposed as a mechanism for MINOCA due to AF [12].

Additional risk factors in $\mathrm{CE}$ patients are chronic valvular disease with or without a history of rheumatic heart disease and prosthetic heart valves. Complications of chronic valvular disease and malfunctioning prosthetic valves usually include heart failure and/or pulmonary hypertension, rather than MI [13,14,15]. Abnormal blood flow and changes in left atrial volume caused by mitral valve disease, especially in $\mathrm{AF}$, may cause thrombus formation $[16,17]$ thereby contributing to thromboembolic CE. Thrombosed prosthetic valves have the potential to cause thromboembolic events [18] and may cause CE this way.

Chest pain was the presenting complaint in $66.8 \%$ of $\mathrm{CE}$ cases, but it is not specific for ischemia and does not distinguish MI due to CE from MI-CAD [19]. Shortness of breath, found in $3.35 \%$ of patients, is also a classic symptom for MI-CAD. Fever, found in $19.0 \%$ of cases, is an unusual symptom of an underlying cardiac issue except in infective endocarditis (IE) and pericarditis [20]. In cases where CE was later determined to have been caused by IE, fever was the initial complaint $69.8 \%$ of the time. Stroke was the initial reason for hospitalization in 2 cases, reinforcing that $\mathrm{CE}$ can be caused by a similar mechanism as embolic CVD.

Diagnostic investigations included ECG in $94.4 \%$ of cases, angiography in $74.6 \%$, TTE in $40.5 \%$, and TEE in $27.2 \%$. The most common ECG finding was ST-elevation, followed by "infarct changes" and AF. These reports did not provide enough data to draw conclusions about how CE presents on ECG versus MI-CAD. Vessel distribution, determined angiographically, followed a similar pattern to MI-CAD [21]. However, micro-emboli and advancement of CE into small caliber vessels may lead to infarction in territories of angiographically normal vessels, contributing to underdiagnosis [22,23]. TTE identified the probable embolic source in $40.4 \%$ of cases when performed and TEE identified the probable source in $76.2 \%$. TEE is $92 \%$ sensitive and $98 \%$ for detecting thrombi in the left atrial appendage, which is the most common area for thrombus formation [24,25,26]. TEE is $90 \%$ sensitive for native valve endocarditis and $85 \%$ sensitive for prosthetic and device-related endocarditis [27].

Causes of CE were varied, but primarily involved pathology of the aortic and mitral valves. Prevalence of 
endocarditis (22.8\%) was high in this population despite less than $4 \%$ of patients having a known history of endocarditis, valve vegetations, and intravenous drug use. $44.4 \%$ of patients had conditions predisposing to IE, including chronic valvular disease, prosthetic valves, and rheumatic heart disease [28]. This association of CE and IE may be a useful step towards creating a predictive tool for CE, especially because the Duke criteria for predicting IE is well-validated [29]. Additionally, since the incidence of IE has increased over a 10-year period in the United States [30], it may become easier to assess prevalence of $\mathrm{CE}$ and the need for specific management strategies in IE patients.

Iatrogenic $\mathrm{CE}$ occurred most commonly in valve repair, valve replacement, and PCI at an overall rate equal to AF. Coronary catheterization is the best studied in this context, having been reported to cause CE with subtherapeutic heparinization or insufficient flushing of coagulated blood in the catheter, as well as incomplete aspiration of air [31,32]. These procedures likely have unique risks for CE, warranting further investigation.

Nearly every case reviewed initially treated the patient for presumptive MI-CAD, with antiplatelet therapy, symptomatic treatment, and angiography playing a central role. Thrombectomy, particularly aspiration thrombectomy was the most frequently chosen intervention, followed by PCI with or without stent placement. Reason for using aspiration thrombectomy versus PCI were not explicitly states in these cases, though previous international guidelines recommend routine use of aspiration thrombectomy with primary PCI and in cases of increased risk factors or high thrombus burden [17]. There was no difference in mortality at 180-days and a slightly higher incidence of stroke for patients who underwent aspiration [33]. In the present study, all patients who underwent PCI survived, while 4 deaths occurred after aspiration thrombectomy. The ability to pathological examine relatively intact aspiration specimens has enhanced current understanding of the causes of $\mathrm{CE}$, in spite of its questionable survival benefits.

Anticoagulation was the most common medical therapy given, with $14.7 \%$ of patients receiving it in the hospital and $43.1 \%$ receiving it upon discharge. Thrombolytic therapy was also given, most often as the primary therapy [34], though its use is not well-studied and may even result in distalization of the thromboembolism to a smaller branch [35]. In the absence of clear guidelines, therapeutic approach to CE in patients of clinical presentation varies greatly. Reasons for not including other therapies including risk of stent infection in endocarditis [36], lack of evidence for thrombolytic therapy [37], and "free floating” emboli determined unlikely to respond to angioplasty [38].

Death occurred at a higher rate in cases where CE was not explicitly treated. Mortality was $93.5 \%$ in patients receiving no intervention or symptomatic treatment, $58.8 \%$ in patients treated with antibiotics or antifungals alone, and $48.0 \%$ in patients treated with anticoagulation alone. One study [8] showed CE MI patients had a significantly higher mortality rate (hazard ratio 3.82) and cardiac death rate (HR, 5.39; 95\% CI, 2.38-10.6) than MI-CAD patients, which underscores the need for better understanding of CE.

\section{Conclusion}

$\mathrm{CE}$ is an understudied cause of MI. The at-risk populations appear to be younger and more male than the general MI-CAD population and have unique risk factors in addition to those typically associated MI-CAD, including $\mathrm{AF}$ and valvular heart disease. While clinical presentation and ECG was indistinct from MI-CAD, TTE and TEE often demonstrated an embolic focus. When the clinical picture is considered alongside imaging, the most likely causes of CE were determined to be endocarditis with valvular involvement, malfunctioning or thrombosed prosthetic heart valves, intracardiac thrombi, and atrial fibrillation. There are no validated diagnostic algorithms for CE and as such it should be considered a possibility alongside the more traditional causes of MI, especially when the patient has known valve pathology or hemodynamically compromised valves on echocardiography. Definitive management strategies are challenging, in part due to the heterogeneity of causes of CE. The study shows that, in cases where the embolism itself was not directly addressed by thrombectomy, PCI, or thrombolysis, CE mortality was high.

\section{Acknowledgements}

This work is supported, in part, by the efforts of Dr. Moro O. Salifu M.D., M.P.H., M.B.A., M.A.C.P., Professor and Chairman of Medicine through NIH Grant number S21MD012474.

\section{References}

[1] Xu J, Murphy SL, Kochanek KD, Bastian B, Arias E. Deaths: final data for 2016. National vital statistics reports: from the Centers for Disease Control and Prevention, National Center for Health Statistics, National Vital Statistics System. 2018 Jul; 67(5): 1-76.

[2] Benjamin EJ, Muntner P, Bittencourt MS. Heart disease and stroke statistics-2019 update: a report from the American Heart Association. Circulation. 2019; 139(10): e56-28.

[3] Ambrose JA, Singh M. Pathophysiology of coronary artery disease leading to acute coronary syndromes. F1000prime reports. 2015; 7.

[4] Scalone G, Niccoli G, Crea F. Editor's choice-Pathophysiology, diagnosis and management of MINOCA: an update. European Heart Journal: Acute Cardiovascular Care. 2019 Feb; 8(1): 54-62.

[5] Pasupathy S, Air T, Dreyer RP, Tavella R, Beltrame JF. Systematic review of patients presenting with suspected myocardial infarction and nonobstructive coronary arteries. Circulation. 2015 Mar 10; 131(10): 861-70.

[6] Raphael CE, Heit JA, Reeder GS, Bois MC, Maleszewski JJ, Tilbury RT, Holmes Jr DR. Coronary embolus: an underappreciated cause of acute coronary syndromes. JACC: Cardiovascular Interventions. 2018 Jan 22; 11(2): 172-80.

[7] PRIZEL KR, HUTCHINS GM, BULKLEY BH. Coronary artery embolism and myocardial infarction: a clinicopathologic study of 55 patients. Annals of internal medicine. 1978 Feb 1; 88(2): 155-61.

[8] Shibata T, Kawakami S, Noguchi T, Tanaka T, Asaumi Y, Kanaya T, Nagai T, Nakao K, Fujino M, Nagatsuka K, Ishibashi-Ueda H. Prevalence, clinical features, and prognosis of acute myocardial infarction attributable to coronary artery embolism. Circulation. 2015 Jul 28; 132(4): 241-50.

[9] NHANES Questionnaires, Datasets, and Related Documentation https://wwwn.cdc.gov/nchs/nhanes/continuousnhanes/default.aspx ?BeginYear=2015. 
[10] Mehta LS, Beckie TM, DeVon HA, Grines CL, Krumholz HM, Johnson MN, Lindley KJ, Vaccarino V, Wang TY, Watson KE, Wenger NK. Acute myocardial infarction in women: a scientific statement from the American Heart Association. Circulation. 2016 Mar 1; 133(9): 916-47.

[11] Cheng JT, Cahill WJ, Foley EF. Coronary embolism. Journal of the American Medical Association. 1953 Sep 19; 153(3): 211-3.

[12] Soliman EZ, Safford MM, Muntner P, Khodneva Y, Dawood FZ, Zakai NA, Thacker EL, Judd S, Howard VJ, Howard G, Herrington DM. Atrial fibrillation and the risk of myocardia infarction. JAMA internal medicine. 2014 Jan 1; 174(1): 107-14.

[13] Maganti K, Rigolin VH, Sarano ME, Bonow RO. Valvular heart disease: diagnosis and management. InMayo Clinic Proceedings 2010 May 1 (Vol. 85, No. 5, pp. 483-500). Elsevier.

[14] Okello E, Wanzhu Z, Musoke C, Kakande B, Mondo CK, Freers J, Twalib A, Lwabi P, Wilson NB, Odoi-Adome R. Cardiovascular complications in newly diagnosed rheumatic heart disease patients at Mulago Hospital, Uganda. Cardiovascular journal of Africa. 2013 Apr; 24(3): 82.

[15] Roudaut R, Serri K, Lafitte S. Thrombosis of prosthetic heart valves: diagnosis and therapeutic considerations. Heart. 2007 Jan 1; 93(1):137-42.

[16] Iscan S, Dönmez K, Çakir H, Kestelli M. LA thrombus formation in mitral valve disease. Anadulu Kardiyoloji Dergisi: AKD. 2016 Dec $1 ; 16(12): 992$.

[17] Watson T, Shantsila E, Lip GY. Mechanisms of thrombogenesis in atrial fibrillation: Virchow's triad revisited. The Lancet. 2009 Jan 10; 373(9658):155-66.

[18] Biteker M, Altun I, Basaran O, Dogan V, Yildirim B, Ergun G. Treatment of prosthetic valve thrombosis: current evidence and future directions. Journal of clinical medicine research. 2015 Dec; 7(12):932.

[19] Thygesen K, Alpert JS, Jaffe AS, Chaitman BR, Bax JJ, Morrow DA, White HD, Mickley H, Crea F, Van de Werf F, BucciarelliDucci C. Fourth universal definition of myocardial infarction (2018). European heart journal. 2019 Jan 1; 40(3):237-69.

[20] Smid J, Scherner M, Wolfram O, Groscheck T, Wippermann J, Braun-Dullaeus RC. Cardiogenic Causes of Fever. Deutsches Ärzteblatt International. 2018 Mar; 115(12):193.

[21] Wasilewski J, Niedziela J, Osadnik T, Duszańska A, Sraga W, Desperak P, Myga-Porosiło J, Jackowska Z, Nowakowski A, Głowacki J. Predominant location of coronary artery atherosclerosis in the left anterior descending artery. The impact of septal perforators and the myocardial bridging effect. Kardiochirurgia i torakochirurgia polska= Polish journal of cardiothoracic surgery. 2015 Dec; 12(4): 379.

[22] Kolodgie FD, Virmani R, Finn AV, Romero ME. Embolic myocardial infarction as a consequence of atrial fibrillation: a prevailing disease of the future.

[23] Henriques JP, Zijlstra F, Ottervanger JP, De Boer MJ, Van'T Hof AW, Hoorntje JC, Suryapranata H. Incidence and clinical significance of distal embolization during primary angioplasty for acute myocardial infarction. European heart journal. 2002 Jul 1; 23(14): 1112-7

[24] Beigel R, Wunderlich NC, Ho SY, Arsanjani R, Siegel RJ. The left atrial appendage: anatomy, function, and noninvasive evaluation. JACC: Cardiovascular imaging. 2014 Dec 1; 7(12): 1251-65.

[25] Acar J, Cormier B, Grimberg D, Kawthekar G, Iung B, Scheuer B, Farah E. Diagnosis of left atrial thrombi in mitral stenosisusefulness of ultrasound techniques compared with other methods. European heart journal. 1991 Jul 1; 12(suppl_B): 70-6.

[26] Manning WJ, Weintraub RM, Waksmonski CA, Haering JM, Rooney PS, Maslow AD, Johnson RG, Douglas PS. Accuracy of transesophageal echocardiography for identifying left atrial thrombi: a prospective, intraoperative study. Annals of Internal Medicine. 1995 Dec 1; 123(11): 817-22.

[27] Harding D, Prendergast B. Advanced imaging improves the diagnosis of infective endocarditis. F1000Research. 2018; 7.

[28] Ambrosioni J, Hernandez-Meneses M, Téllez A, Pericàs J, Falces C, Tolosana JM, Vidal B, Almela M, Quintana E, Llopis J, Moreno A. The changing epidemiology of infective endocarditis in the twenty-first century. Current infectious disease reports. 2017 May 1; 19(5): 21.

[29] Topan A, Carstina D, Slavcovici A, Rancea R, Capalneanu R, Lupse M. Assesment of the Duke criteria for the diagnosis of infective endocarditis after twenty-years. An analysis of 241 cases. Clujul Medical. 2015; 88(3): 321.

[30] Pant S, Patel NJ, Deshmukh A, Golwala H, Patel N, Badheka A Hirsch GA, Mehta JL. Trends in infective endocarditis incidence, microbiology, and valve replacement in the United States from 2000 to 2011. Journal of the American College of Cardiology. 2015 May 19; 65(19): 2070-6.

[31] Park CB, Hwang HJ, Cho JM, Jo BH, Kim CJ. Massive right coronary air embolism in the right coronary artery during left coronary angiography: A case report. Experimental and therapeutic medicine. 2013 Apr 1; 5(4): 1073-4.

[32] Tavakol M, Ashraf S, Brener SJ. Risks and complications of coronary angiography: a comprehensive review. Global journal of health science. 2012 Jan; 4(1): 65.

[33] Levine GN, Bates ER, Blankenship JC, Bailey SR, Bittl JA, Cercek B, Chambers CE, Ellis SG, Guyton RA, Hollenberg SM, Khot UN. 2015 ACC/AHA/SCAI focused update on primary percutaneous coronary intervention for patients with ST-elevation myocardial infarction: an update of the 2011 ACCF/AHA/SCAI guideline for percutaneous coronary intervention and the 2013 ACCF/AHA guideline for the management of ST-elevation myocardial infarction. Journal of the American College of Cardiology. 2016 Mar 15; 67(10): 1235-50.

[34] Aykan AC, Ozkan M, Duran NE, Yildiz M. Acute ST-elevation inferior myocardial infarction in a patient with a non-obstructive mechanical mitral valve thrombosis: case report-online article. Cardiovascular journal of Africa. 2012 Oct 1; 23(9): 7-8.

[35] Aslam MS, Sanghi V, Hersh S, Lakier JB. Coronary artery saddle embolus and myocardial infarction in a patient with prosthetic mitral valve. Catheterization and cardiovascular interventions. 2002 Nov; 57(3): 367-70.

[36] Winkler J, Chaudhry SP, Stockwell PH. Gemella endocarditis presenting as an ST-segment-elevation myocardial infarction. Texas Heart Institute Journal. 2016 Jun; 43(3): 258-60.

[37] Nakazone MA, Tavares BG, Machado MN, Maia LN. Acute myocardial infarction due to coronary artery embolism in a patient with mechanical aortic valve prosthesis. Case reports in medicine. 2010; 2010.

[38] Steinwender C, Hofmann R, Hartenthaler B, Leisch F. Resolution of a coronary embolus by intravenous application of bivalirudin. International journal of cardiology. 2009 Mar 6; 132(3): e115-6.

[39] MORAGUES V, BAWELL MB, SHRADER EL. Coronary embolism: review of the literature and report of a unique case. Circulation. 1950 Sep; 2(3): 434-7.

[40] Walker B. Coronary embolism and coronary occlusion in bacterial endocarditis. British heart journal. 1952 Jan; 14(1): 144.

[41] GLUSHIEN AS, REITER MD, FISCHER H. Coronary embolism (intra vitam diagnosis) and necrotizing renal papillitis: case report. Annals of internal medicine. 1952 Feb 1; 36(2_Part_2): 679-85.

[42] Segall HN, Harris M. Coronary embolism with unusual features Canadian Medical Association journal. 1954 Apr; 70(4): 416.

[43] Gill III TJ, McBride RA, Dammin GJ. Coronary embolism: Report of three cases. American Heart Journal. 1958 Dec 1; 56(6):878-89.

[44] HOFFMAN MS, FORREST J, GARLETT EL. Coronary Embolism and Acute Myocardial Infarction Secondary to Rheumatic Heart Disease. CHEST. 1958 May 1; 33(5):546-50.

[45] Lillington GA, Connolly DC, Kavanaugh GJ. Coronary embolism secondary to subacute bacterial endocarditis in a case of calcific aortic stenosis. InProceedings of the staff meetings. Mayo Clinic 1958 Apr 30 (Vol. 33, No. 9, p. 216).

[46] Kavanaugh GJ, Pruitt RD, Edwards JE. Coronary embolism and cystic medial necrosis of ascending aorta associated with calcific aortic stenosis. InProceedings of the staff meetings. Mayo Clinic 1958 Apr (Vol. 33, No. 9, pp. 222-228).

[47] Boas NF, Barnett RN. Coronary Embolism With Myocardial Infarction-Complication of Verrucous Endocarditis. Journal of the American Medical Association. 1959 Aug 8; 170(15): 1804-8.

[48] GELPI AP, Ende N. Coronary embolus with myocardial infarction and rupture. Annals of internal medicine. 1959 Feb 1; 50(2): 511-9.

[49] Wenger NK, Bauer S. Coronary embolism: review of the literature and presentation of fifteen cases. The American journal of medicine. 1958 Oct 1; 25(4): 549-57.

[50] Marietta JS. Acute bacterial endocarditis and coronary embolism. Texas state journal of medicine. 1960 Jun; 56: 426-8. 
[51] Winters Jr WL, LAUTSCH EV, SOLOFF LA. Coronary embolism following repair of a ventricular septal defect. Circulation. 1960 Jan; 21(1): 77-9.

[52] Menzies CJ. Coronary embolism with infarction in bacterial endocarditis. British heart journal. 1961 Jul; 23(4): 464.

[53] Oakley C, Yusuf R, Hollman A. Coronary embolism and angina in mitral stenosis. British heart journal. 1961 Jul; 23(4): 357.

[54] MIYAHARA M, NAGASAKI Y, HIGASHI H, TSUKAD H. A Case of Intravitam Diagnosis of Coronary Embolism. Japanese circulation journal. 1961 Oct 15; 25(10): 1014-8.

[55] Jerie P, Poddany V. Coronary embolism in mitral stenosis. Cardiologia. 1962; 40: 281-9.

[56] Shanoff HM, Balshin B. Coronary embolism in rheumatic heart disease. Canadian Medical Association journal. 1962 Jul 7; 87(1): 5.

[57] Rivera R, Tallon R. CORONARY EMBOLISM IN MITRAL STENOSIS. The Journal of cardiovascular surgery. 1964; 5: 382.

[58] Liban E. CORONARY EMBOLISM IN A YOUNG WOMAN WITH RHEUMATIC HEART DISEASE. Israel journal of medical sciences. 1965 Mar; 1: 307-11.

[59] Harris LS, Adelson L. Fatal coronary embolism from a myxomatous polyp of the aortic valve: an unusual cause of sudden death. American journal of clinical pathology. 1965 Jan 1; 43(1): 61-4.

[60] Watt DA. Paradoxical coronary embolism. British heart journal. 1966 Jul; 28(4): 570.

[61] Ritch DL, Drew DW. Coronary embolism with myocardial infarction and septic meningitis in a young female with subacute bacterial endocarditis. Virginia medical monthly. 1967 Apr; 94(4): 224-8.

[62] Woo-Ming MO, Summerell J. Dissociated ventricular rhythm. A case observed following a coronary embolus during closed initial commissurotomy. The Journal of cardiovascular surgery. 1968; 9(3): 288.

[63] Tsuchiya G, KAWAMORI K, MORIMOTO M, INOH T, TOMOMATSU T, MORI Y. A Case of Coronary Embolism in Mitral Steno-insufficiency: Clinical and Pathological Survey. Japanese circulation journal. 1969 Apr 20; 33(2): 139-44.

[64] Parameswaran R, Meadows WR, Sharp JT. Coronary embolism in primary myocardial disease. American heart journal. 1969 Nov 1; 78(5): 682-7.

[65] Reddy CR, Ramakrishna MR, Krishnaiah LG, Damodar VR. Coronary embolism in mitral stenosis. Indian heart journal. 1969 Apr; 21(2): 233-40.

[66] Hall WT, Mac JG. Coronary embolism with survival. Case report. Delaware medical journal. 1967 May; 39(5): 125-7.

[67] Benchimol A, Sandoval J. Coronary embolism in patients with mitral valve prosthesis. Chest. 1971 Nov 1; 60(5):431-6.

[68] Richardson PM, Gotsman MS. Angiographic evidence of coronary embolism and resolution. South African Medical Journal. 1971; 45(7):805-9.

[69] Hartveit F, Andersen KS, Maehle BO, Kalager T. Fatal coronary embolism due to thrombus detached from a coronary catheter. A case report. Acta pathologica et microbiologica Scandinavica. Supplement. 1974:95-9.

[70] Schatz JW, Fischer JA. Paradoxic coronary embolism in a patient with mid-systolic click syndrome. Chest. 1974 Nov 1; 66(5):58790.

[71] Attai LA, Delman AJ, Robinson G. Coronary Embolism Following Mitral Valve Replacement: Intraoperative Diagnosis and Successful Embolectomy. The Annals of thoracic surgery. 1974 Aug 1; 18(2):191-4.

[72] Pfeifer JF, Lipton MJ, Oury JH, Angell WW, Hultgren HN. Acute coronary embolism complicating bacterial endocarditis: operative treatment. The American journal of cardiology. 1976 May 1; 37(6):920-2.

[73] Olusegun Fayemi A, Deppisch LM. Coronary embolism and myocardial infarction associated with nonbacterial thrombotic endocarditis. American journal of clinical pathology. 1977 Sep 1; 68(3):393-6.

[74] Bedetti CD, Siewers RD, Dunsford HA. Teflon felt embolism of coronary arteries after cardiac surgery: a case report. American heart journal. 1978 Dec 1; 96(6):802-5.

[75] Saenz CB, Harrell RR, Sawyer Iii JA, Hood Jr WP. Acute percutaneous transluminal coronary angioplasty complicated by embolism to a coronary artery remote from the site of infarction. Catheterization and cardiovascular diagnosis. 1987 Jul; 13(4): 266-8.

[76] Sridhar K, Chandra KS, Dikshit V. Coronary embolism in a patient with mitral prosthesis treated by coronary angioplasty--a case report. Indian heart journal. 1997; 49(2):181.

[77] McHenry MM, Lee JO. Skeletal muscle coronary embolism: a complication of coronary angiography. Circulation. 1979 Jan; 59(1):189-91.

[78] Lin CS, Zak FG. Paradoxical bone marrow coronary embolism following cardiopulmonary resuscitation. Jama. 1982 Jul 2; 248(1):33-.

[79] Przybojewski JZ. Acute transmural myocardial infarctioncoronary vasospasm, thrombosis or coronary embolus? A case report.

[80] Przybojewski JZ, Tredoux JG, Van Der Walt JJ, Tiedt FA. Mitral valve prolapse complicated by acute cerebral embolism, arrhythmias and painless myocardial infarction. A case presentation and overview.

[81] Marx JD, Kleynhans PH, Otto AC. Lysis of a coronary embolus by intracoronary streptokinase. A case report. South African medical journal= Suid-Afrikaanse tydskrif vir geneeskunde. 1985 Aug; 68(5):346-9.

[82] Ueda M, Becker AE, Fujimoto T, Tamai H. Bacterial endocarditis of the aortic valve with septic coronary embolism and myocardial infarction in a 4-month old baby. European heart journal. 1986 May 1; 7(5):449-51.

[83] Presant S, Vandormael M, Kern MJ. Paradox of acute myocardial ischemia and successful PTCA: A case report of subtle coronary embolus. American heart journal. 1986 Dec 1; 112(6):1317-9.

[84] Culver RA, Bampton PA, Bignold LP. Aortic and coronary embolism of anaplastic small - cell carcinoma of the lung. Medical journal of Australia. 1987 Nov; 147(9):455-6.

[85] Maddoux GL, Goss JE, Ramo BW, Raff GL, Heuser RR, Shadoff N, Wilson JN, Deane WM, Hoyt TW, Fowler BN, Gerety RL. Left main coronary artery embolism: a case report. Catheterization and cardiovascular diagnosis. 1987 Nov; 13(6):394-7.

[86] Ackermann DM, Hyma BA, Edwards WD. Malignant neoplastic emboli to the coronary arteries: Resport of two cases and review of the literature. Human pathology. 1987 Sep 1; 18(9):955-9.

[87] Mercereau D, Klinke WP. Paradoxical coronary embolism associated with an unusual interatrial flap valve. The Canadian journal of cardiology. 1988 Apr; 4(3):140-3.

[88] Backer CL, Hartz RS, Meyers SN, Davis G. Coronary embolism following atrial septal defect repair. The Annals of thoracic surgery. 1988 May 1; 45(5):561-3.

[89] Jungbluth A, Erbel R, Darius H, Rumpelt HJ, Meyer J. Paradoxical coronary embolism: case report and review of the literature. American heart journal. 1988 Sep 1; 116(3):879-85.

[90] Vasiljevic JD, Abdulla AK. Coronary embolism by metastatic choriocarcinoma of the uterus: an unusual cause of ischemic heart disease. Gynecologic oncology. 1990 Aug 1; 38(2):289-92.

[91] Herzog CA, Henry TD, Zimmer SD. Bacterial endocarditis presenting as acute myocardial infarction: a cautionary note for the era of reperfusion. The American journal of medicine. 1991 Mar 1; 90(3):392-7.

[92] Valente M, Basso C, Thiene G, Bressan M, Stritoni P, Cocco P, Fasoli G. Fibroelastic papilloma: a not-so-benign cardiac tumor. Cardiovascular Pathology. 1992 Apr 1; 1(2):161-6.

[93] Bell C, Kern MJ, Aguirre F, Miller L, Bach R, Donohue T, Dressler F. Coronary atherectomy complicated by coronary embolus in a cardiac transplant recipient. American heart journal. 1993 Apr 1; 125(4):1172-5.

[94] Eckstein FS, Schäfers HJ, Grote J, Mügge A, Borst HG. Papillary fibroelastoma of the aortic valve presenting with myocardial infarction. The Annals of thoracic surgery. 1995 Jul 1; 60(1): 206-8.

[95] Haynes PA. Fatal paradoxical coronary embolism. JOURNALROYAL ARMY MEDICAL CORPS. 1996 Jun 1; 142:82-3.

[96] Abascal VM, Kasznica J, Aldea G, Davidoff R. Left atrial myxoma and acute myocardial infarction: a dangerous duo in the thrombolytic agent era. Chest. 1996 Apr 1; 109(4):1106-8.

[97] IWAMA T, Asami K, Kubo I, KITAZUME H. Hypertrophic cardiomyopathy complicated with acute myocardial infarction due to coronary embolism. Internal medicine. 1997; 36(9):613-7. 
[98] Quinn EG, Fergusson DJ. Coronary embolism following aortic and mitral valve replacement: successful management with abciximab and urokinase. Catheterization and cardiovascular diagnosis. 1998 Apr; 43(4):457-9.

[99] Matsumoto M, Konishi Y, Miwa S, Minakata K. Mycotic aneurysm of the left coronary artery. The Annals of thoracic surgery. 1998 Mar 1; 65(3):841-2.

[100] Lanza GM, Berman BJ, Taniuchi M. Multifocal coronary thromboembolism from a left ventricular thrombus. New England Journal of Medicine. 1999 Sep 30; 341(14): 1083-4.

[101] Perera R, Noack S, Dong W. Acute myocardial infarction due to septic coronary embolism. New England Journal of Medicine. 2000 Mar 30; 342(13): 977-8.

[102] Takada A, Saito K, Ro A, Tokudome S, Murai T. Papillary fibroelastoma of the aortic valve: a sudden death case of coronary embolism with myocardial infarction. Forensic science international. 2000 Sep 11; 113(1-3): 209-14.

[103] Tun A, Khan IA. Acute myocardial infarction with angiographically normal coronary arteries. Heart \& lung. 2000 Sep 1; 29(5): 348-50.

[104] Chan S, Silver MD. Fatal myocardial embolus after myectomy. The Canadian journal of cardiology. 2000 Feb; 16(2): 207-11.

[105] Mentzelopoulos SD, Kokotsakis JN, Romana CN, Karamichali EA. Intracoronary thrombolysis and intraaortic balloon counterpulsation for the emergency treatment of probable coronary embolism after repair of an acute ascending aortic dissection. Anesthesia \& Analgesia. 2001 Jul 1; 93(1):56-9.

[106] Aslam MS, Sanghi V, Hersh S, Lakier JB. Coronary artery saddle embolus and myocardial infarction in a patient with prosthetic mitral valve. Catheterization and cardiovascular interventions. 2002 Nov; 57(3):367-70.

[107] BELDNER S, BAJWA A, KAPLAN B, ROSEN S, STEINBERG B, CACCIABAUDO J. Septic Coronary Embolism 1. Journal of interventional cardiology. 2002 Aug; 15(4):301-4.

[108] Hernández F, Pombo M, Dalmau R, Andreu J, Alonso M, Albarrán A, Velázquez MT, Tascón JC. Acute coronary embolism: angiographic diagnosis and treatment with primary angioplasty. Catheterization and cardiovascular interventions. 2002 Apr; 55(4):491-4.

[109] Tobar R, Kriwisky M, Rozenman Y, Harpaz D. Acute myocardial infarction caused by coronary embolism complicated by left ventricular free wall rupture. Journal of the American Society of Echocardiography. 2001 Jul 1; 14(7):754-6.

[110] Hung WC, Wu CJ, Chen WJ, Yang CH, Chang JP. Transradial Intracoronar Cathete-Aspiration Embolectomy for Acute Coronary Embolism after Mitral Valve Replacement. Texas Heart Institute Journal. 2003; 30(4):316.

[111] Ramos AD, Medeiros AR, Paulista PP, Abboud CS, Meneghelo ZM. Aspergillus infection in the ascending aorta of a patient with aortic and mitral valve prostheses. Arquivos brasileiros de cardiologia. 2003 Oct; 81(4):419-20.

[112] Meier-Ewert HK, Labib SB, Schick EC, Gossman DE, Stix MS, Williamson CA. Paradoxical embolism in the left main coronary artery: diagnosis by transesophageal echocardiography. InMayo Clinic Proceedings 2003 Jan 1 (Vol. 78, No. 1, pp. 103-106). Elsevier.

[113] Kotooka N, Otsuka Y, Yasuda S, Morii I, Kawamura A, Miyazaki S. Three cases of acute myocardial infarction due to coronary embolism. Japanese heart journal. 2004; 45(5):861-6.

[114] Mahmood Z, Cook DS, Luckraz H, O'Keefe P. Fatal right ventricular infarction caused by Bioglue coronary embolism. The Journal of thoracic and cardiovascular surgery. 2004 Nov 1; 128(5):770-1.

[115] Haghi D, Sueselbeck T, Papavassiliu T, Haase KK, Borggrefe M. Paradoxical coronary embolism causing non-ST segment elevation myocardial infarction in a case of pulmonary embolism. Zeitschrift für Kardiologie. 2004 Oct 1; 93(10):824-8.

[116] Eguchi K, Ohtaki E, Misu K, Aikawa M, Sumiyoshi T, Hosoda S, Koyanagi T. Acute myocardial infarction caused by embolism of thrombus in the right coronary sinus of Valsalva: a case report and review of the literature. Journal of the American Society of Echocardiography. 2004 Feb 1; 17(2):173-7.

[117] Orban M, Tousek P, Becker I, Augustin N, Firschke C. Cardiac malignant tumor as a rare cause of acute myocardial infarction. The international journal of cardiovascular imaging. 2004 Feb 1; 20(1):47-51.
[118] Petinaux B, Shesser R, Rah B, Reiner J. Coronary embolus secondary to a prosthetic mitral valve and subtherapeutic anticoagulation. The American journal of emergency medicine. 2004 Jul 1; 22(4):318-20.

[119] Ozaydin M, Dogan A, Altinbas A. Left atrial myxoma presenting with acute myocardial infarction: a case report. Angiology. 2005 Nov; 56(6):767-9.

[120] Adachi I, Kobayashi J, Nakajima H, Niwaya K, Ishibashi-Ueda H, Bando K, Tagusari O. Coronary embolism and subsequent myocardial abscess complicating ventricular aneurysm and tachycardia. The Annals of thoracic surgery. 2005 Dec 1; 80(6):2366-8.

[121] Tukaye DN, Cavallazzi RS. Paradoxical thromboembolism/STelevation myocardial infarction via a patent foramen ovale in submassive pulmonary embolism following an upper extremity deep venous thrombosis: is it time for a change in the standard of care?. Cardiology research. 2014 Aug; 5(3-4):112.

[122] Braun S, Schrötter H, Reynen K, Schwencke C, Strasser RH. Myocardial infarction as complication of left atrial myxoma. International journal of cardiology. 2005 May 11; 101(1):115-21.

[123] Taniike M, Nishino M, Egami Y, Kondo I, Shutta R, Tanaka K, Adachi T, Tanouchi J, Yamada Y, Kawano K. Acute myocardial infarction caused by a septic coronary embolism diagnosed and treated with a thrombectomy catheter. Heart. 2005 May 1; 91(5):e34-.

[124] Pindado J, Marcos-Alberca P, Rey M, Rábago R, de Diego C, Ibáñez B, Córdoba M, Farré J. Incomplete myocardial rupture after coronary embolism of an isolated single coronary artery. European Journal of Echocardiography. 2005 Jan 1; 6(1):72-4.

[125] Kirkpatrick EC, Hurwitz R. Myocardial infarction late after Mustard procedure. Pediatric cardiology. 2005 Feb 1; 26(1):97100.

[126] Vanoverbeke H. Coronary embolism from mitral fibro-elastoma. European journal of cardio-thoracic surgery. 2006 Aug 1; 30(2):383-.

[127] Kiernan TJ, Flynn AM, Kearney P. Coronary embolism causing myocardial infarction in a patient with mechanical aortic valve prosthesis. International journal of cardiology. 2006 Sep 20; 112(2):E14-6.

[128] Mejia VM, Woo YJ, Herrmann HC. Left main coronary embolism. The Journal of invasive cardiology. 2006 Jun; 18(6):296-.

[129] Çay S, Topaloğlu S, Korkmaz S. Acute coronary embolism after mitral valve replacement in a patient presenting with non-STsegment elevation myocardial infarction. Anadolu kardiyoloji dergisi: $\mathrm{AKD}=$ the Anatolian journal of cardiology. 2006 Jun; 6(2):210-.

[130] Bodor E, Jánosi A, Szilard D, Balogh O. Surgically treated intraoperative coronary embolism. The Thoracic and cardiovascular surgeon. 2006 Mar; 54(02):142-4.

[131] Bracco D, Noiseux N, Duong P, Prieto I, Basile F. Aortic vegetation and acute coronary embolism. The Canadian journal of cardiology. 2006 Feb; 22(2):113.

[132] Breithardt OA, Papavassiliu T, Borggrefe M. A coronary embolus originating from the interatrial septum. European heart journal. 2006 May 25; 27(23):2745-

[133] Wilson AM, Ardehali R, Brinton TJ, Yeung AC, Vagelos R. Successful removal of a paradoxical coronary embolus using an aspiration catheter. Nature Reviews Cardiology. 2006 Nov; 3(11):633.

[134] Yazici M, Kayrak M, Turan Y, Koc F, Ulgen MS. Acute coronary embolism without valve thrombosis in a patient with a prosthetic mitral valve--successful percutaneous coronary intervention: a case report. InThe heart surgery forum 2007 (Vol. 10, No. 3, pp. E228-30).

[135] Sakai K, Inoue K, Nobuyoshi M. Aspiration thrombectomy of a massive thrombotic embolus in acute myocardial infarction caused by coronary embolism. International heart journal. 2007; 48(3):387-92.

[136] Van de Walle S, Dujardin K. A case of coronary embolism in a patient with paroxysmal atrial fibrillation receiving tamoxifen. International journal of cardiology. 2007 Dec 15; 123(1):66-8.

[137] Ural E, Bildirici U, Kahraman G, Komsuoğlu B. Coronary embolism complicating aortic valve endocarditis: treatment with successful coronary angioplasty. International journal of cardiology. 2007 Jul 31; 119(3):377-9. 
[138] Greig LD, Leslie SJ, Denvir MA. Paradoxical coronary embolism in a young woman. International journal of cardiology. 2007 Jan 31; 115(1):E17-9.

[139] Yavari A, Paul G, Jackson G. Aborted sudden cardiac death-a rare presentation of septic coronary embolism. European journal of internal medicine. 2008 Nov 1; 19(7):559.

[140] Caciolli S, Rostagno C, Fradella G, Margheri M, Stefano P. Coronary embolism following valve surgery. Journal of Cardiovascular Medicine. 2008 Apr 1; 9(4):406-7.

[141] Baek MJ, Kim HK, Yu CW, Na CY. Mitral valve surgery with surgical embolectomy for mitral valve endocarditis complicated by septic coronary embolism. European Journal of CardioThoracic Surgery. 2008 Jan 1; 33(1):116-8.

[142] Kessavane A, Marticho P, Zogheib E, Lorne E, Dupont H, Tribouilloy C, Remadi JP. Septic coronary embolism in aortic valvular endocarditis. J Heart Valve Dis. 2009 Sep 1; 18(5):572-4.

[143] Nanjappa MC, Shankarappa RK, Chandrasekaran D, Moorthy N. Fatal coronary embolism in infective endocarditis associated with chronic rheumatic heart disease: an unexpected transesophageal echocardiographic documentation. Echocardiography. 2009 Aug; 26(7):870-2.

[144] Murthy A, Shea M, Karnati PK, El-Hajjar M. A rare case of paradoxical embolism causing myocardial infarction: Successfully aborted by aspiration alone. Journal of cardiology. 2009 Dec 1; 54(3): 503-6.

[145] Martín E, Vázquez A, Hornero F. Incidental Finding of Coronary Embolism During Valve Surgery. Revista española de cardiología. 2009 Nov 1; 62(11):1337-8.

[146] Camaro C, Aengevaeren WR. Acute myocardial infarction due to coronary artery embolism in a patient with atrial fibrillation. Netherlands Heart Journal. 2009 Aug 1; 17(8):297-9.

[147] Lacunza-Ruiz FJ, Gimeno-Blanes JR, Pinar-Bermúdez E, ValdésChávarri M. Coronary embolism after percutaneous implantation of an aortic valve prosthesis. Revista española de cardiología. 2009 Sep 1; 62(09):1074-5.

[148] Sial JA, Ferman MT, Saghir T, Rasool SI. Coronary embolism causing acute myocardial infarction in a patient with mitral valve prosthesis: successful management with angioplasty. JPMA. The Journal of the Pakistan Medical Association. 2009 Jun; 59(6):409.

[149] Budavari AI, Glenn TJ, Will KK, Askew JW, Fortuin FD. A case of simultaneous pulmonary embolism and acute myocardial infarction secondary to a previously undiagnosed patent foramen ovale. Journal of Hospital Medicine: An Official Publication of the Society of Hospital Medicine. 2009 May; 4(5):E5-9.

[150] Teixeira R, Lourenco C, Coelho L, Vieira H, Ramos D, Castro G, Monteiro P, Donato P, Ferreira MJ, Providência LA. Carney complex: a case report. Revista portuguesa de cardiologia: orgao oficial da Sociedade Portuguesa de Cardiologia $=$ Portuguese journal of cardiology: an official journal of the Portuguese Society of Cardiology. 2009 Feb; 28(2):211-22.

[151] Lin TC, Hsieh YC, Lee WL, Lin YK, Ting CT, Wu TJ. Acute embolic myocardial infarction in a patient with paroxysmal atrial fibrillation receiving direct-current cardioversion. Journal of the Chinese Medical Association. 2009 Mar 1; 72(3):146-9.

[152] Dogan M, Acikel S, Aksoy MM, Cagirci G, Kilic H, Yesilay A, Akdemir R. Coronary saddle embolism causing myocardial infarction in a patient with mechanical mitral valve prosthesis: treatment with thrombolytic therapy. International Journal of Cardiology. 2009 Jun 26; 135(2):e47-8.

[153] Steinwender C, Hofmann R, Hartenthaler B, Leisch F. Resolution of a coronary embolus by intravenous application of bivalirudin. International journal of cardiology. 2009 Mar 6; 132(3):e115-6.

[154] Shim JK, Choi YS, Yoo KJ, Kwak YL. Carbon dioxide embolism induced right coronary artery ischaemia during off-pump obtuse marginalis artery grafting. European Journal of Cardio-Thoracic Surgery. 2009 Sep 1; 36(3):598-9.

[155] Ferlan G, Fiorella A, De Pasquale C, Tunzi F. Primary coronary embolism as an unusual manifestation of nonbacterial thrombotic endocarditis in a patient with gastric cancer. Cardiology research and practice. 2010; 2010.

[156] Nakazone MA, Tavares BG, Machado MN, Maia LN. Acute myocardial infarction due to coronary artery embolism in a patient with mechanical aortic valve prosthesis. Case reports in medicine. 2010; 2010.

[157] Pawlaczyk R, Lango R, Klapkowski A, Rogowski J. Low cardiac output due to left main coronary embolism during mitral valve replacement. Journal of cardiac surgery. 2010 Nov; 25(6):658-60.
[158] Motreff P, Roux A, Souteyrand G. Aspiration therapy in septic coronary embolism complicating infectious endocarditis. Heart. 2010 May 1; 96(10):809-.

[159] Bae KR, Lee YS, Kim BK, Ha GJ, Kim SY, Choi JY, Kim KS. A case of acute myocardial infarction caused by distal embolization of a left main coronary artery thrombus. Korean circulation journal. 2010 Jan 1; 40(1):46-9.

[160] Yuce M, Yavuz F, Cakici M, Sari I, Davutoglu V. A rare cause of myocardial infarction: coronary embolism in a patient with prosthetic mitral valve thrombosis.

[161] Levis JT, Schultz G, Lee PC. Acute myocardial infarction due to coronary artery embolism in a patient with a tissue aortic valve replacement. The Permanente Journal. 2011; 15(3):82.

[162] Saraiva F, Matos V, Gonçalves L, Providência LA. Acute coronary embolism in a patient with a mechanical aortic prosthesis: case report. Revista portuguesa de cardiologia: orgao oficial da Sociedade Portuguesa de Cardiologia $=$ Portuguese journal of cardiology: an official journal of the Portuguese Society of Cardiology. 2011 May; 30(5):543-9.

[163] Gavrielatos G, Buttner HJ, Lehane C, Neumann FJ. Complex interventional procedures for the management of early postoperative left main coronary artery embolism after bioprosthetic aortic valve insertion. Cardiovascular Revascularization Medicine. 2011 Jan 1; 12(1):68-e1.

[164] George JC, Buchanan D, Mazzoni J. Thrombectomy and fibrinolytic therapy of prosthetic valve thrombosis complicated by coronary embolism. The Journal of invasive cardiology. 2011 Jan; 23(1): E243-5.

[165] Najib MQ, Lee HR, DeValeria PA, Vinales KL, Surapaneni P, Chaliki HP. Anterolateral papillary muscle rupture: an unusual complication of septic coronary embolism. European Journal of Echocardiography. 2010 Sep 28; 12(2):E10-.

[166] Acikel S, Dogan M, Aksoy MM, Akdemir R. Coronary embolism causing non-ST elevation myocardial infarction in a patient with paroxysmal atrial fibrillation: treatment with thrombus aspiration catheter. International journal of cardiology. 2011 May 19; 149(1):e33-5.

[167] Roxas CJ, Weekes AJ. Acute myocardial infarction caused by coronary embolism from infective endocarditis. The Journal of emergency medicine. 2011 May 1; 40(5):509-14.

[168] Rifai L, Trabolsi M, Dia M. Coronary embolus complicating peripartum cardiomyopathy. The Journal of invasive cardiology. 2011 Oct; 23(10):E237-40.

[169] Vasconcellos AP, Korr KS. Spontaneous calcific coronary embolus from a degenerative calcific aortic valve-a rare cause of acute ST segment elevation myocardial infarction. The American heart hospital journal. 2011; 9(1):E55-9.

[170] Aykan AC, Ozkan M, Duran NE, Yildiz M. Acute ST-elevation inferior myocardial infarction in a patient with a non-obstructive mechanical mitral valve thrombosis: case report-online article. Cardiovascular journal of Africa. 2012 Oct 1; 23(9):7-8.

[171] Martin SS. Biatrial thrombus across a patent foramen ovale with fatal pulmonary and coronary embolism. Journal of echocardiography. 2012 Jun 1; 10(2):77-8.

[172] Marella PC, Murarka S, Talluri SK, Bashir F. "Snake” Shaped Vegetation in Right Coronary Artery. North American journal of medical sciences. 2012 Aug; 4(8):373.

[173] Bennett J, Ong L, Hanratty C. Paradoxical coronary embolism, a rare cause of acute myocardial infarction on positive pressure ventilation. Acta cardiologica. 2012 Aug 1; 67(4):477-9.

[174] Staico R, Armaganijan L, Lopes RD. Coronary embolism and calcified aortic valve: is there a correlation?. Journal of thrombosis and thrombolysis. 2012 Oct 1; 34(3):425-7.

[175] Brito JD, Almeida MS, Ribeiras R, Melo JQ, Almeida RH, Silva JA. Recurrent myocardial infarction in a patient with papillary fibroelastoma. Arquivos brasileiros de cardiologia. 2012 Jan; 98(1):e7-10.

[176] Kaya H, Ertas F, Tekbas E, Elbey MA. Resolution of obstructive prosthetic valve thrombosis after coronary embolism/Koroner emboli sonrasi düzelen tikayici protez kapak trombüsü. Anadulu Kardiyoloji Dergisi: AKD. 2012 Feb 1; 12(1):E3.

[177] Kim HL, Seo JB, Chung WY, Zo JH, Kim MA, Kim SH. Simultaneously presented acute ischemic stroke and non-ST elevation myocardial infarction in a patient with paroxysmal atrial fibrillation. Korean circulation journal. 2013 Nov 1; 43(11):766-9.

[178] Karavelioğlu Y, Yanartaş M, Sarak T, Bakal RB, Özkan M Coronary embolism in a patient with massive left atrial thrombus 
and mechanical valve thrombus: hybrid treatment with surgery and percutaneous intervention. Archives of the Turkish Society of Cardiology. 2013 Dec 1; 41(8):784-.

[179] Smith JG, Koul S, Roijer A, Holmqvist J, Keussen I, Cwikiel W, Öhlin B, Erlinge D. Acute right ventricular failure caused by concomitant coronary and pulmonary embolism: successful treatment with endovascular coronary and pulmonary thrombectomy. European Heart Journal: Acute Cardiovascular Care. 2013 Jun; 2(2):131-6.

[180] Angulo - Llanos R, Sanz - Ruiz R, Solis J, Fernández - Avilés F. Acute myocardial infarction: an uncommon complication of takotsubo cardiomyopathy. Catheterization and Cardiovascular Interventions. 2013 Nov 15; 82(6):909-13.

[181] Zasada W, Bartuś S, Królikowski T, Dudek D. Patient with atrial fibrillation and myocardial infarction due to coronary artery embolism treated with thrombus aspiration. Kardiologia polska. 2013; 71(1):99-101.

[182] Kirubakaran S, Zuberi Z, Gill J. Acute myocardial infarction due to a coronary embolus during left atrial ablation for persistent atrial fibrillation. Europace. 2012 Jul 9; 15(2):211-.

[183] Tiong S, Williams MJ, Perez DJ. Nonbacterial thrombotic endocarditis with ST-elevation myocardial infarction treated with percutaneous coronary aspiration thrombectomy. Heart, Lung and Circulation. 2013 May 1; 22(5):386-9.

[184] Lacunza-Ruiz FJ, Muñoz-Esparza C, García-de-Lara J. Coronary embolism and thrombosis of prosthetic mitral valve. JACC: Cardiovascular Interventions. 2014 Oct 1; 7(10):e127-8.

[185] Tsang MY, Calvin AD, Reeder GS, Ammash NM, Hammack JE, Melduni RM. New-onset chest pain and palpitation. Heart. 2014 Nov 15; 100(22):1814-5.

[186] Karakoyun S, Gürsoy MO, Kalçık M, Yesin M, Özkan M. A case series of prosthetic heart valve thrombosis-derived coronary embolism. Turk Kardiyol Dern Ars. 2014 Jul 1; 42(5):467-71.

[187] Abecasis J, Ribeiras R, Gabriel HM, Andrade MJ. Thrombus entrapment: the clue for coronary embolism. European heart journal. 2014 Jun 6; 35(42):2971-.

[188] Giri S, Hwang I, Alsafwah S. A case of left main coronary artery embolus further embolising to the left anterior descending artery. BMJ case reports. 2014 May 28; 2014:bcr2013203159.

[189] Gagliardi L, Guerbaai RA, Marlière S, Bouvaist H, Ennezat PV. Coronary embolization following electrical cardioversion in a patient treated with dabigatran. International journal of cardiology. 2014 Aug 20; 175(3):571-2.

[190] Seo GW, Seol SH, No TH, Jeong HJ, Kim TJ, Kim JK, Song PS, Kim DK, Kim KH, Kim DI. Acute myocardial infarction caused by coronary embolism from Aspergillus endocarditis. Internal Medicine. 2014; 53(7):713-6.

[191] Kitkungvan D, Denktas AE. Cardiac arrest and ventricular tachycardia from coronary embolism: an unusual presentation of infective endocarditis. Anadulu Kardiyoloji Dergisi: AKD. 2014 Mar 1; 14(2):204.

[192] Dauvergne C, Araya M, Valenzuela J, Meneses M, Selman R, Maluenda G. Acute myocardial infarction after left-heart catheterization in a patient with severe calcified bicuspid aortic stenosis. JACC: Cardiovascular Interventions. 2014 Feb 1; 7(2):e5-6.

[193] Šteiner I, Vojáček J. Carcinoma embolization in coronary artery causing myocardial infarction: diagnosis from coronary thromboaspirate. Pathology-Research and Practice. 2014 Mar 1; 210(3):198-200.

[194] Heseltine TD, Karthikeyan VJ, Morris J. Takotsubo cardiomyopathy with secondary coronary embolus. Case Reports. 2014 Apr 23; 2014:bcr2013203145.

[195] Wee CK, Gosavi TD, Huang W. The Clot Strikes Thrice: Case Report of a Patient with 3 Concurrent Embolic events. Acta Neurologica Taiwanica. 2015 Sep; 24(3):92-6.

[196] Senguttuvan NB, Ramakrishnan S, Singh S, Mishra S. Percutaneous management of coronary embolism with prosthetic heart valve thrombosis after Bentall's procedure. Indian heart journal. 2015 Nov 1; 67(6):589-91.

[197] Plymen C, Pettit SJ, Tsui S, Lewis C. Right ventricular failure due to late embolic RV infarction during continuous flow LVAD support. BMJ case reports. 2015 Dec 16; 2015:bcr2015212174.

[198] Iannaccone M, Montefusco A, D'ascenzo F, Moretti C. All that glitters ain't gold! A case of embolic STEMI demonstrated by OCT. International journal of cardiology. 2015 Oct 1; 196:14-5.
[199] Medda M, Casilli F, Ghommidh EM, Bande M, Inglese L. Aortic valve cusps decalcification complicated by an embolic myocardial infarction treated by transradial intracoronary embolectomy. JACC: Cardiovascular Interventions. 2015 Jun 1; 8(7):e121-3.

[200] Wongrakpanich S, Thamcharoen N, Chongsathidkiet P, Siwamogsatham S. Dual prosthetic heart valve presented with chest pain: a case report of coronary thromboembolism. Case reports in cardiology. 2015; 2015.

[201] Mallouppas M, Christopoulos C, Watson W, Cader R, Cooper J. An uncommon complication of atrial fibrillation. Oxford medical case reports. 2015 Mar 1; 2015(3):232-4.

[202] Nakamura D, Makino N, Egami Y, Shutta R, Tanouchi J, Nishino M. Successful thrombectomy for coronary embolism likely due to floating aortic plaque in ascending aorta. Cardiovascular intervention and therapeutics. $2015 \mathrm{Jul}$ 1; 30(3):299-302.

[203] Mallouppas M, Vassiliou V, Goddard M, Rana B, Braganza D. An unusual complication of hip surgery: paradoxical coronary embolism of foreign material as a cause of acute MI. EuroIntervention. 2014.

[204] Hartung B, Gahr B, Ritz-Timme S. Pulmonary and coronary foreign particle embolism after central venous injection of liquid nutrition. Forensic science international. 2015 Feb 1; 247:e18-20.

[205] Sultan A, Goela A, Tweedie E, Awan K, Lavi S. Multimodality Imaging for Assessment of Coronary Embolus. Canadian Journal of Cardiology. 2015 Mar 1; 31(3):364-e5.

[206] Koutsampasopoulos K, Datsios A, Grigoriadis S, Vogiatzis I. Atrial fibrillation causing ST elevation myocardial infarction due to coronary embolism: case report and review of the literature. Hippokratia. 2016 Apr; 20(2):160.

[207] Castelli JB, Almeida G, Siciliano RF. Sudden death in infective endocarditis. Autopsy \& case reports. 2016 Jul; 6(3):17.

[208] Winkler J, Chaudhry SP, Stockwell PH. Gemella endocarditis presenting as an ST-segment-elevation myocardial infarction. Texas Heart Institute Journal. 2016 Jun; 43(3):258-60.

[209] Zachura M, Sadowski M, Janion-Sadowska A, Kurzawski J, Janion M. Acute myocardial infarction due to coronary embolism originating from left ventricle thrombus in a patient with dilated cardiomyopathy and sinus rhythm. Postepy w Kardiologii Interwencyjnej. 2016; 12(1):73.

[210] Ito S, Endo A, Okada T, Nakamura T, Adachi T, Nakashima R, Sugamori T, Takahashi N, Yoshitomi H, Tanabe K. Acute myocardial infarction due to left atrial myxoma. Internal Medicine. 2016; 55(1):49-54.

[211] Sousa C, Almeida J, Dias P, Almeida P, Rangel I, Araújo V, Macedo F, Maciel MJ. Conservative Management of a Prosthetic Valve Thrombosis-Report of a Successful Case. Heart, Lung and Circulation. 2014 Oct 1; 23(10):e207-9.

[212] Nogales-Romo MT, Tirado G, Freitas-Ferraz A, Martínez-Losas P, Rodrigo JL, Alswies A, Saiz-Pardo M, Ruiz-Mateos B, VianaTejedor A, Fernández-Ortiz A, Macaya C. Coronary embolism of left atrial myxoma coexisting with severe aortic stenosis and atherosclerotic coronary disease. International journal of cardiology. 2016 Jan 15; 203:315-6.

[213] Chikkabasavaiah N, Rajendran R, Beeresha P, Ramesh B. Percutaneous Coronary Intervention for Coronary Thromboembolism during Balloon Mitral Valvuloplasty in a Pregnant Woman. Heart, Lung and Circulation. 2016 Feb 1; 25(2):e29-31.

[214] Rozado J, Pascual I, Avanzas P, Moris C. Coronary Embolism After Iatrogenic Radial Endarterectomy. The Journal of invasive cardiology. 2016 Jun; 28(6):E54-5.

[215] Rotta DL, Rawluk J, Krauss T, Bode C, Moser M, Helbing T. Acute transmural myocardial infarction by coronary embolism in a patient with JAK2 V617F-positive essential thrombocythemia. Hamostaseologie. 2017 Jul 10; 99(99).

[216] Liu G, Yang P, He Y. Left ventricular mural thrombus and dual coronary embolization associated with hyperthyroid cardiomyopathy and atrial fibrillation: a case report. BMC cardiovascular disorders. 2017 Dec; 17(1):128.

[217] Rivera-Juárez A, Sarnago-Cebada F, Díez-Delhoyo F, Cuerpo G, Hortal J, Fernandez-Avilés F. Cardiogenic shock due to septic coronary embolism: treatment options for a rare entity. Clinical Research in Cardiology. 2017 Aug 1; 106(8):660-2.

[218] Sinha SK, Jha MJ, Razi M, Chaturvedi V, Erappa YB, Singh S, Mishra V, Khanra D, Singh K. Acute Myocardial Infarction Due to Coronary Artery Embolism in a 22-Year-Old Woman with Mitral Stenosis with Atrial Fibrillation Under Warfarinization: 
Successful Management with Anticoagulation. The American journal of case reports. 2017; 18:361.

[219] Manchurov V, Anisimov K, Khokhlova V, Skrypnik D. The first reported stentriever-based thrombectomy in acute ST-elevation myocardial infarction due to paradoxical coronary embolism. EuroIntervention: journal of EuroPCR in collaboration with the Working Group on Interventional Cardiology of the European Society of Cardiology. 2017 Aug 4; 13(5):e602.

[220] Pavani M, Conrotto F, D'Ascenzo F, D'Amico M, Centofanti P, Gaita F. Left main occlusion secondary to infective endocarditis vegetation: "The unusual suspect". Cardiovascular Revascularization Medicine. 2017 Jul 1; 18(5):367-8.

[221] Dallaglio PD, Claver E, Di Marco A, Alió J, Hidalgo A, Cequier A. Double-chambered left ventricle: coronary embolism as the first presentation of an extremely unusual cardiac anomaly. Journal of Cardiovascular Medicine. 2017 Oct 1; 18(10):790-2.

[222] Martinez FE, Ryden L, Leaver R, Mendoza J, Havill K. Fungal coronary embolus while on extracorporeal membrane oxygenation. Anaesthesia and intensive care. 2017 Sep 1; 45(5):634A.

[223] Cvetković D, Živković V, Nikolić S. Patent foramen ovale, paradoxical embolism and fatal coronary obstruction. Forensic Science, Medicine and Pathology. 2018 Jun 1; 14(2):258-62.

[224] Sakagami A, Okura H, Uemura T, Saito Y. Inter-atrial Septal Thrombus without PFO. Internal Medicine. 2018 Feb 1; 57(3):445-.

[225] Jiao ZY, Zhang DP, Xia K, Wang LF, Yang XC. Clinical analysis of acute myocardial infarction caused by coronary embolism. Journal of thoracic disease. 2017 Sep; 9(9):2898.

[226] Ahmad K, Asirvatham S, Kamath S, Peck S, Liu X. Successful interventional management of catastrophic coronary arterial air embolism during atrial fibrillation ablation. HeartRhythm case reports. 2016 Mar; 2(2):153.

[227] Cay S, Ozeke O, Ozcan F, Topaloglu S, Aras D. Coronary Air Embolism during Cryoablation of Atrial Fibrillation: A Catastrophic Complication and Its Management. Journal of atrial fibrillation. 2017 Oct; 10(3).

[228] Virk HU, Inayat F, Farooq S, Ghani AR, Mirrani GA, Athar MW. Prosthetic aortic valve endocarditis with left main coronary artery embolism: a case report and review of the literature. North American journal of medical sciences. 2016 Jun; 8(6):259.

(C) The Author(s) 2020. This article is an open access article distributed under the terms and conditions of the Creative Commons Attribution (CC BY) license (http://creativecommons.org/licenses/by/4.0/). 